\title{
The copper status of beef cattle in Northern Ireland
}

\author{
By R. H. THOMPSON* AND J. R. TODD* \\ Department of Agriculture, Veterinary Research Laboratories, \\ Stormont, Belfast $B T_{4} 3 S D$, and \\ The Queen's University of Belfast, Belfast BT9 $6 B B$, \\ Northern Ireland
}

(Received 20 April 1976 - Accepted 6 May 1976 )

\begin{abstract}
I. Serum caeruloplasmin (ferroxidase I; $E C$ I.16.3. I) activity has been used as an indicator of copper status of cattle to survey beef herds in Northern Ireland.

2. The main survey covered some 20000 cows on 1200 farms.

3. The results are reported in the form of a map showing areas where herds of low and very-low $\mathrm{Cu}$ status predominate. Clinical signs of $\mathrm{Cu}$ deficiency in calves were encountered in only two areas.
\end{abstract}

The concentrations of copper in either whole blood or serum have been used for many years to assess the $\mathrm{Cu}$ status of various animals, and in particular to indicate deficiency states. Although the estimation of $\mathrm{Cu}$ is relatively simple, rigorous standards of cleanliness have to be maintained at all stages, from the collection of the blood sample to the laboratory determination.

Caeruloplasmin (ferroxidase I; $E C$ I.16.3.I) (CPL) is a plasma protein which contains $\mathrm{Cu}$ as an integral part of the molecule, and its concentration in serum has been found to be directly proportional to the corresponding serum or whole-blood $\mathrm{Cu}$ level (McCosker, Ig6I). CPL is conveniently estimated by its enzymic properties and the specificity of the estimation is such that high standards of cleanliness are not required.

Todd (1970, 197I) has briefly reported the use of CPL estimations on cattle sera as a means of assessing $\mathrm{Cu}$ status. Using this method as a screening procedure, clinical $\mathrm{Cu}$ deficiency was discovered in an area where it was previously not known to occur and there were indications that the $\mathrm{Cu}$ status of beef herds in the country was decreasing.

The object of this communication is to give more details of the procedure used, and to indicate on a map of Northern Ireland, areas where low Cu status in herds has been detected.

\section{MATERIALS AND METHODS}

Blood samples. The samples of serum used were submitted to the laboratory for purposes other than CPL analysis and only those from beef suckler cows were used since these animals are seldom given concentrates, and so the results would reflect the adequacy or otherwise of the herbage grazed in different regions. A preliminary

* Present Address: Agricultural and Food Chemistry Research Division, Newforge Lane, Belfast $\mathrm{B}^{\prime} \mathrm{T}_{9} \mathrm{PX}$, Northern Ireland. 
survey of about 2000 samples was carried out in 1966 . The main survey of about 20000 samples was undertaken in 1969 and 1970 , and smaller surveys have been continued intermittently since then.

Chemical analysis. CPL was estimated essentially by the colorimetric method of Ravin (196r), slightly modified for use with large batches of determinations. The main modifications were reduction of the time of incubation by half, and a compensatory doubling of the volume of serum used. Each batch of determinations contained serum blanks and control sera. The former were duplicate samples where the enzyme activity had been inhibited by the addition of azide, and the latter were reference sera, high and low CPL activity respectively, whose $\mathrm{Cu}$ and $\mathrm{CPL}$ values had been assayed previously. For calibration purposes periodic calculations were made of regression equations for CPL activity (expressed in extinction units) $v$. $\mathrm{Cu}$ content of either the serum or the corresponding whole blood, where the extinction units are the difference in extinction at $530 \mathrm{~nm}$ between the test and blank assays, each containing $0.1 \mathrm{ml}$ serum in a total volume of $5.0 \mathrm{ml}$ after incubation for $30 \mathrm{~min}$ at $37^{\circ}$. These extinction units may be expressed in terms of units of enzyme activity, where one unit is defined as the amount of enzyme which oxidizes I $\mu \mathrm{mol} p$-phenylenediamine/min per 1 serum, by using the procedure described by Rice (1962).

For the determination of $\mathrm{Cu}$, blood was collected into $\mathrm{Cu}$-free bottles. Wholeblood $\mathrm{Cu}$ levels were used in the early part of the work, the $\mathrm{Cu}$ being determined by the method of Brown \& Hemingway (1962). Serum Cu levels were used in later work, the analysis being carried out by the atomic absorption spectrophotometric method described by Thompson \& Blanchflower (1971). The correlation coefficients relating $\mathrm{CPL}$ and $\mathrm{Cu}$ were $0.75^{-0.80}$ for serum $\mathrm{Cu}$ levels ranging from 0.22 to $\mathrm{I} \cdot 33 \mathrm{mg} / \mathrm{l}$.

The individual CPL results were used $(a)$ to classify individual animals in a herd, and $(b)$ to study the geographical distribution of $\mathrm{Cu}$ status on a herd basis. For (a), individual results were classified according to their blood CPL activity into three groups:

$\begin{array}{lcc} & \begin{array}{c}\text { CPL } \\ \text { (extinction units) }\end{array} & \begin{array}{c}\text { Serum Cu equivalent } \\ (\mathrm{mg} / \mathrm{l})\end{array} \\ \text { Normal } & >0.11 & >0.70 \\ \text { Low } & 0.06-0.1 \mathrm{I} & 0.45-0.70 \\ \text { Very low } & <0.06 & <0.45\end{array}$

The distribution of animals in a herd into the three groups was tabulated. If the majority of the animals in a herd were in the 'low' and 'very-low' groups, further blood samples were taken for $\mathrm{Cu}$ estimation and the animals and their calves examined clinically for signs of $\mathrm{Cu}$ deficiency.

For $(b)$, each farm was allocated a six-figure map reference number which served to locate it to within $\mathrm{I} \mathrm{km}$. The mean herd CPL value was then calculated, classified as 'normal', 'low', or 'very-low' according to the ranges given previously, and a map was then prepared outlining areas where 'low' and 'very-low' herds predominated. 


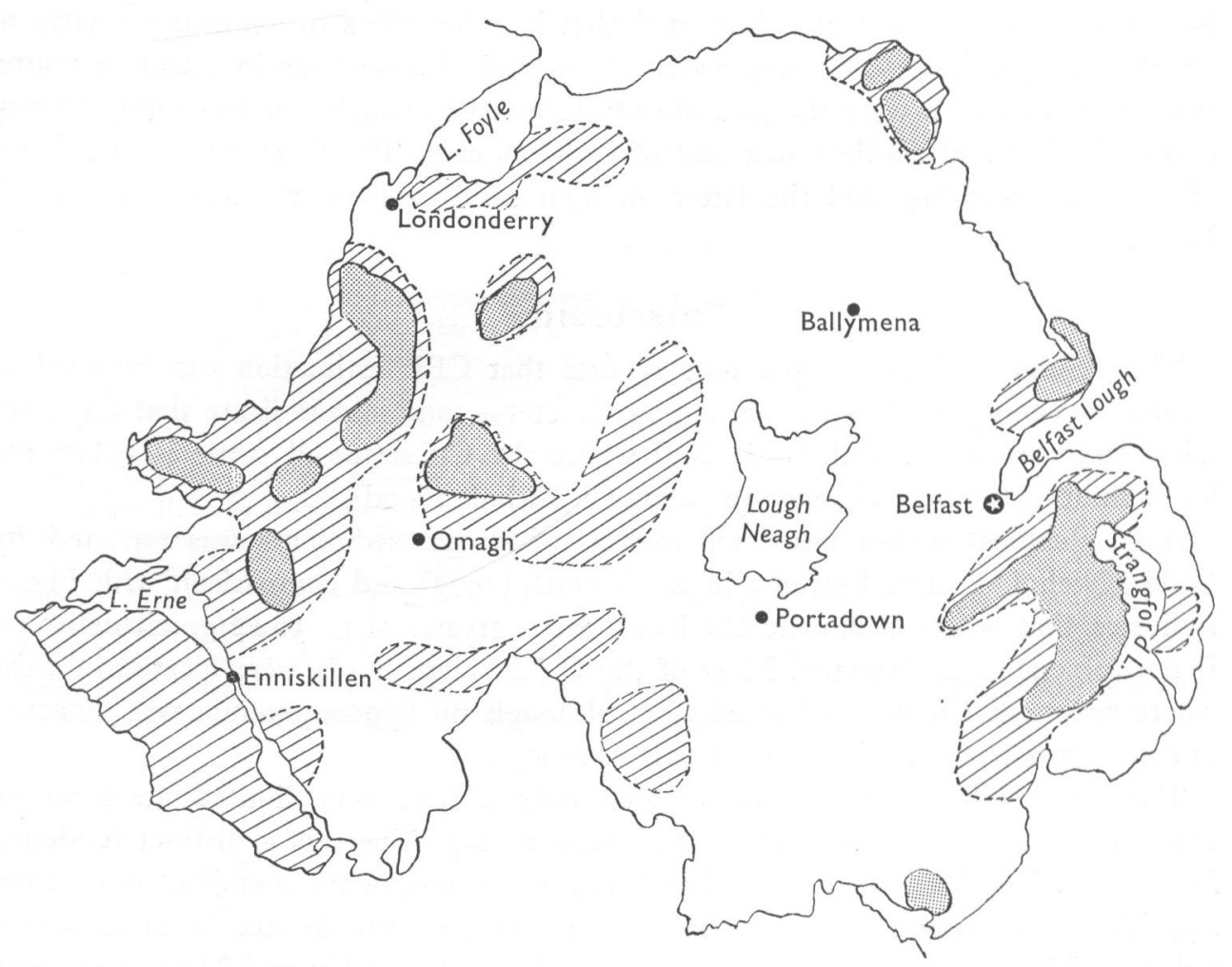

Fig. r. Geographical distribution of copper-deficient herds in Northern Ireland, based on the grouping of mean values for herd $\mathrm{Cu}$ concentrations obtained by analysis of serum

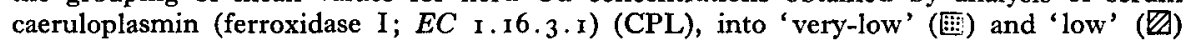
groups for which corresponding serum $\mathrm{Cu}$ concentrations were respectively: $\mathrm{CPL}$ activity $<0.06$ extinction units, $<0.45 \mathrm{mg} \mathrm{Cu} / 1$ serum; CPL activity $0.06-0.1$ I extinction units, $0.45^{-0.70} \mathrm{mg} \mathrm{Cu} / 1$ serum; for details of estimations and units, see page 000 .

\section{RESULTS}

In total, sera from about 20000 cows representing about 1200 farms were analysed. The total numbers of beef cows in Northern Ireland in 1969 and 1970 were 190000 and 208000 respectively so that the survey represents about ro $\%$ of the total number. Although the samples covered approximately 200 herds only about 700 were used in delineating the areas on the map. The others were omitted because insufficient information was available to locate the farms on the map.

Summarized results of the survey are presented in Fig. I which shows the geographical distribution of the areas where herds with 'low' and 'very-low' $\mathrm{Cu}$ status were detected. The areas include districts in the following counties: Tyrone, Londonderry, north-east County Antrim, where the soils are derived from mica schist; parts of Tyrone and Fermanagh, where the soils are derived from carboniferous limestone; mid and east County Down, where the soils are derived from boulder clay of silurian origin.

Clinical examination of cows and their calves on farms where 'low' and 'very 
low' $\mathrm{Cu}$ levels were detected indicated that in most cases no clinical evidence of $\mathrm{Cu}$ deficiency existed. The only areas where clinical symptoms in calves or young stock were observed were the area already referred to which was in County Down, east of Belfast and another area east of Londonderry. The former was on an area of cut-away peat bog and the latter on light sandy soil on the shores of Lough Foyle.

\section{DISCUSSION}

The results confirm our previous reports that CPL estimation can be used as a rapid screening method for estimating $\mathrm{Cu}$ status, and also indicate that there are fairly large areas of Northern Ireland where the $\mathrm{Cu}$ status of cattle is below the lower limit of the normal range ( $0.70 \mathrm{mg} \mathrm{Cu} / \mathrm{l}$ whole blood).

A geochemical survey based on analysis of stream sediments was reported by Webb, Nichol, Foster, Lowenstein \& Howarth (1973) and comparison with Fig. I indicates that where sediment $\mathrm{Cu}$ levels were greater than $56 \mu \mathrm{g} / \mathrm{g}$, virtually no hypocupraemia was detected. Most of the $\mathrm{Cu}$-deficient herds were located in areas where sediment $\mathrm{Cu}$ was below $28 \mu \mathrm{g} / \mathrm{g}$, although no hypocupraemia was detected in some areas where sediment $\mathrm{Cu}$ levels were low.

The geochemical survey also revealed only a few, very limited areas where sediments contained more than $3 \mu \mathrm{g}$ molybdenum/g. There is a distinct tendency for $\mathrm{Cu}$-deficient herds to be found in areas where sediments contained more than $2 \mu \mathrm{g} \mathrm{Mo} / \mathrm{g}$, although some herds of 'low' $\mathrm{Cu}$ status were located in areas where sediment Mo was $\mathrm{I} \mu \mathrm{g} / \mathrm{g}$ or less. The antagonism between $\mathrm{Cu}$ and $\mathrm{Mo}$ in ruminant nutrition is well known (Dick, 1954) but the correlation between the results of stream-sediment analysis and $\mathrm{Cu}$ status of animals need not necessarily be exact since the uptake of Mo by plants is dependent on soil $\mathrm{pH}$ and plant species, and $\mathrm{Cu}$ metabolism in ruminants is influenced by other dietary constituents, such as sulphur, as well as Mo.

Nevertheless it is of interest to note that the two areas where clinical $\mathrm{Cu}$ deficiency occurred were both characterized by high Mo contents in the pasture $\left(5^{-1} 7 \mu \mathrm{g} / \mathrm{g}\right.$ dry matter (DM)). In areas where hypocupraemia without clinical symptoms occurred, pasture Mo levels were generally in the range $\mathrm{I}-4 \mu \mathrm{g} / \mathrm{g}$ DM. The first report of swayback in lambs in Northern Ireland was that of Gracey \& Todd (1958) and subsequent experience indicates a steady increase in incidence over the years and in different areas. In 1971 a number of severe outbreaks occurred (Kavanagh, Purcell \& Thompson, 1972), all of which were found within areas outlined in Fig. I.

Low $\mathrm{Cu}$ status in cattle was first reported in Northern Ireland in I967 (Todd, Milne \& How, I967), but in this instance, although severe hypocupraemia was found in both cows and their calves, no clinical manifestations were observed and no increase in live weight gain was obtained after $\mathrm{Cu}$ supplementation. The cases of clinical $\mathrm{Cu}$ deficiency in calves found during this survey were the first to be identified in Northern Ireland. Comparison of the results of the small survey carried out in 1966 with those of the larger $1969-70$ survey would indicate that the over-all $\mathrm{Cu}$ status of beef cows was lower in 1969 than in 1966 (Todd, 197I). It would 
appear therefore that the $\mathrm{Cu}$ status of ruminants in Northern Ireland is decreasing and the situation requires to be kept under review.

We wish to thank Mr W. J. Blanchflower for skilled assistance.

\section{REFERENCES}

Brown, N. \& Hemingway, R. G. (1962). Res. vet. Sci. 3, 345.

Dick, A. T. (1954). Aust. F. agric. Res. 5, 5 I 1.

Gracey, J. F. \& Todd, J. R. (1958). Vet. Rec. 70, 238.

Kavanagh, P. J., Purcell, D. A. \& Thompson, R. H. (1972). Vet. Rec, 90, 538.

McCosker, P. J. (1961). Nature, Lond. I90, 887.

Ravin, H. A. (1961). F. Lab. clin. Med. 58, 161.

Rice, E. W. (1962). Analyt. Biochem. 3, 452.

Thompson, R. H. \& Blanchflower, W. J. (1971). Lab. Prac. 20, 859.

Todd, J. R. (1970). In Trace Element Metabolism in Animals, p. 448 [C. F. Mills, editor]. Edinburgh and London: E. \& W. Livingstone.

Todd, J. R. (1971). Mineral Studies with Isotopes in Domestic Animals, p. 159. Vienna: International Atomic Energy Agency.

Todd, J. R., Milne, A. A. \& How, P. F. (1967). Vet. Rec. 81, 653.

Webb, J. S., Nichol, I., Foster, R., Lowenstein, P. L. \& Howarth, R. J. (1973). Provisional Geochemical Atlas of Northern Ireland. London: Applied Geochemical Research Group. 